\title{
IMAGEM DO OUTRO E IMAGEM DE SI: \\ OS EDITORIAIS DE O ESTADO DE S. PAULO \\ SOBRE O MOVIMENTO PASSE LIVRE*
}

\author{
Carlos Humberto Ferreira Silva Júnior** \\ Universidade Metodista de São Paulo, São Bernardo do Campo, SP
}

RESUMO

O trabalho tem, como objetivo, analisar a imagem discursiva que o jornal O Estado de S. Paulo apresenta sobre o Movimento Passe Livre (MPL). Foram analisados dois editoriais, publicados em janeiro de 2016, nos quais esse movimento é citado nominalmente. Como metodologia, utilizou-se a proposta de antecipação das representações do receptor, oferecida por Michel Pêcheux, no texto Análise Automática do Discurso. Em nossa conclusão, percebemos que o jornal apresenta visão negativa do MPL, associando, ao movimento, valores como desorganização, desrespeito ao jogo democrático, violência, delinquência e criminalidade, ao mesmo tempo que manifesta imagem de si como fiscalizador, desafiador do poder público, juiz e conselheiro da sociedade.

Palavras-chave: Comunicação, Jornalismo, O Estado de S. Paulo, Movimento Passe Livre, MPL.

\section{TEXTO DO TRABALHO}

Durante as manifestações de junho de 2013, o Movimento Passe Livre (MPL) passou a ter maior visibilidade social, fixando sua imagem na esfera pública. O MPL foi responsável inicial pela convocação dos atos que deram fôlego às diversas demandas sociais emergentes naquele período. A partir dessa inclusão no cotidiano social, tal movimento passou a ter um significado: tornou-se marcadamente conhecido pela reivindicação de transporte público e gratuito para todos. Assim, o MPL passou a ser referência, principalmente para os jovens, no debate sobre o transporte urbano.

* Trabalho apresentado no GT Comunicação Popular e Alternativa, do PENSACOM BRASIL 2016.

** Mestrando no Programa de Pós-graduação em Comunicação (Pós com) da Universidade Metodista de São Paulo. E-mail: carlos ferreira_jr@yahoo.com.br 
Então. como foi a reação da imprensa para com esse movimento? Segundo Venicio A. de Lima (LIMA IN MARICATO... [et al], 2013, p.92), durante as manifestações "a primeira reação [da imprensa] foi de condenação pura e simples. [...]. À medida, no entanto, que o fenômeno se alastrou, a velha mídia alterou radicalmente sua avaliação inicial".

Com o objetivo de entender a imagem que o jornal O Estado de S. Paulo apresentou sobre o MPL, propõe-se, nesse trabalho, uma análise de discurso de dois editoriais, publicados pelo impresso em janeiro de 2016, três anos após as primeiras manifestações. O primeiro editorial, Ordem nas Manifestações, publicado em 14 de janeiro, declara a necessidade de notificação sobre os trajetos das manifestações às autoridades da cidade de São Paulo. Já o segundo editorial, $A$ Verdadeira Face do MPL, veiculado em 17 de janeiro de 2016, discorre sobre a publicação de um manual feito pelo movimento e distribuído aos manifestantes.

Esses dois editoriais analisados têm, como plano de fundo, as novas manifestações do grupo contra o aumento, na cidade de São Paulo, das passagens de ônibus e de metrô de $R \$ 3,50$ para $R \$ 3,80$, que ocorreu no mesmo mês e ano do material selecionado.

Para analisar os editoriais, tomou-se, como base, a proposta de Michel Pêcheux (2010), que, no texto Análise Automática do Discurso, propõe uma fórmula intitulada Antecipação das Representações do Receptor (PÊCHEUX, 2010, p. 83). Nesse esquema de análise, pressupõe-se que o autor da mensagem — no caso, O Estado de S. Paulo —, ao produzir o discurso, já possui imagem prévia dos destinatários. Segundo Pêcheux, duas perguntas são feitas por quem produz o discurso: "Quem sou eu para lhe falar assim?" e "Quem é ele para que eu lhe fale assim? ". Ou seja, durante a produção do editorial, o jornal teve de se perguntar quem era o destinatário e o papel que o próprio jornal possuía no contexto social no qual estava inserido. Na hipótese de Pêcheux, os lugares de A (produtor) e de B (destinatário) aparecem representados no texto, marcados por suas relações e posições:

Nossa hipótese é a de que esses lugares estão representados nos processos discursivos em que são colocados em jogo. Entretanto, seria ingênuo supor que o lugar como feixe de traços objetivos funciona como tal no interior do processo discursivo; ele se encontra aí representado, isto é, presente, mas transformado; em outros termos, o que funciona nos processos discursivos é uma série de formações imaginárias que designam o lugar que A e B se atribuem cada um a

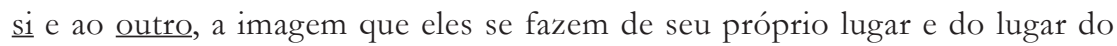


outro. Se assim ocorre, existem nos mecanismos de qualquer formação social regras de projeção, que estabelecem as relações entre as situações (objetivamente definíveis) e as posições (representações destas situações). (PÊCHEUX, 2010, p. 81-82, grifos do autor)

Proposto pelo autor, esse pequeno trecho de esquema bastante complexo pode elucidar muitos pontos na análise que sugerimos.

Desse modo, utilizam-se alguns critérios para a identificação e para a análise desses dois momentos nos editoriais do jornal. Primeiramente, para identificar em quais momentos o jornal fez imagem prévia do MPL (além da citação nominal do movimento), serão consideradas citações indiretas e palavras utilizadas pelo jornal para caracterizar seus integrantes como manifestantes, militantes, simpatizantes, baderneiros, vândalos etc. Já o principal critério usado para a identificação da imagem que o jornal fez de si, constitui um trecho em que o discurso transitou explicitamente da esfera narrativa para a argumentativa.

O Estado de S. Paulo possui diversos destinatários. Porém, de acordo com a metodologia proposta por Pêcheux, o próprio Movimento Passe Livre (MPL) pode ser definido como o destinatário principal da mensagem. Isso porque o jornal cita nominalmente o MPL, o que determina, mesmo indiretamente, que seu discurso será alcançado por esse receptor. $\mathrm{Na}$ análise, portanto, ter-se-á como parâmetro que, ao citar o MPL, O Estado de S. Paulo acaba por escrever, idealizando também, e talvez principalmente, esse movimento, além de seus leitores.

Por fim, o objetivo principal desse trabalho é estabelecer quais são os momentos, expressos nos editoriais, em que o jornal transmite uma imagem prévia do MPL e em que utiliza a imagem de instituição midiática estabelecida e reconhecida socialmente para validar seu discurso.

\section{ORDEM NAS MANIFESTACÕES}

O editorial Ordem nas Manifestações (Figura 1), publicado em 14 de janeiro de 2016, divide a página A3 com outros dois textos: um com o título Como Não Saber de Nada, que coloca em dúvida o não envolvimento das altas autoridades da República no esquema de corrupção conhecido como Petrolão. Já o segundo, intitulado $O$ Agronegócio Salvador, apresenta o agronegócio brasileiro como um caso de sucesso da economia nacional. 


\section{Ordem nas manifestações}

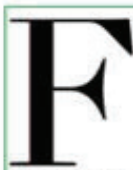

inalmente as autoridades encarregadas da segurança pública decidiram que daqui para a frente os percursos de todas as manifestações realizadas na capital paulista deverảo ser comunicados com antecedencia. Caso contrário, a Policia Militar (PM) estabelecerá o ítinerário a ser seguido. A nâo observância dessa regra elementar é uma das principais responsáveis pelos transtornos provocados por manifestantes, que prejudicam seriamente a população.

Isso começou a valer no protesto organizado na última terça-feira pelo Movimento Passe Livre (MPL) contra o aumento das passagens de ônibus, trens e metrô de RS 3.50 para $\mathrm{R}_{3} 3_{3.80}$ e foi a recusa desse grupo de acatar aquela decisão - como tem feito seguidamente, apesar da insistência das autoridades que desencadeou os tumultos na regiāo da Avenida Paulista, Rua da Consolação e bairros da Bela Vista e de Higienópolis, que assistiram a cenas de violência poucas vezes vistas por ali.

Ao contrário do roteiro decidido em cima da hora pelo MPL para os manifestantes concentrados na Avenida Paulista - seguir pela Avenida Rebouças até o Largo da Batata -, a PM determinou que o percurso deveria ser a Rua da Consolação até a Praça da República. Por isso, bloqueou o acesso à Reboucas, cercou os manifestantes e deteve vários suspeitos com correntes, tesouras, soco inglês e arte- fatos explosivos, numa clara demonstraçào de qual era o ânimo de pelo menos boa parte deles. Para deter os manifestantes que tentaram forçar a passagem, a PM usou bombas de gás lacrimogêneo e de efeito moral.

A posição do MPL, exposta por sua porta-voz Erica de Oliveira - "Quem define o rumo da manifestaçầo é quem se manifesta e não a Polícia Militar" - , é preocupante, porque indica que esse grupo está mesmo disposto a afrontar a autoridade, como já havia demonstrado na terça-feira. Essa é uma visào deliberadamente distorcida da questão, para servir a interesses políticos e ideológicos.

A regra anunciada pelo secretário de Segurança Pública, Alexandre de Moraes é que coloca as coisas em seus devidos lugares: "पQuando o trajeto não for avisado, ele será combinado no momento e o tracado da PM vai ser cumprido. Nầ é possivel que os manifestantes $\mathrm{e}$ infiltrados queiram livremente baguncar a cidade toda. Um grupo de pessoas nào pode parar a cidade e prejudicar milhôes de pessoas". Isso quer dizer que o direito à livre manifestação tem de ser respeitado e nâo, como vinha acontecendo, utilizado para atropelar outros direitos, como o de ir e vir dos que não participam de protestos ou que, quando se manifestam, o fazem dentro da lei e da ordem. A autorizaçào de manifestaçōes, com roteiros previamente comunicados às autoridades, que protegem seus participantes, e a regra seguida nos paises de sólida tradiçẫo democrática, como os europeus e os Estados Unidos. Quem se arrisca a desrespeitá-la paga o preço da repressão policial e grupos violentos como o Black Bloc têm de acertar contas com a Justiça.

Se o governo paulista se mantiver firme nessa nova posiçâo, muita coisa vai mudar, e para melhor. no respeito às liberdades. Principalmente se, além disso, como promete o secretário Moraes, daqui para a frente as ações daqueles grupos forem tipificadas em inquéritos policiais como as de membros de organização criminosa. É inaceitável que baderneiros que destroem patrimônio público e privado sejam detidos, logo liberados e voltem a delinquir.

Ao contrário do governo do Estado, que tomou o bom caminho, o prefeito Fernando Haddad fica muito mal nessa história, com sua proposta demagógica e de viés eleitoreiro de sugerir ao Ministério Público que tente mediar a relação entre o MPL e a PM Os anos gastos na companhia da tigrada devem ter feito o académico Haddad se esquecer de que ordem pública não se negocia - se mantém - e a polícia existe para isso. Aliás, segurança pública é assunto que não diz respeito ao prefeito. E do Ministério Público o que se espera é que aja com firmeza em sua esfera de competência contra ps desordeiros. Mas o pior da atitude de Haddad é a tentativa mesquinha de tirar proveito eleitoral de um problema dessa importância $\mathbf{e}$ gravidade.

\section{Legenda}

Imagem que o jomal faz do MPL

Imagem que o jornal faz de si 
No editorial selecionado, foram identificados onze momentos nos quais o jornal responde à questão "Quem é ele [MPL] para que eu lhe fale assim? ", e seis momentos nos quais $O$ Estado de $S$. Paulo se coloca como autoridade e responde à pergunta "Quem sou eu para lhe falar assim?".

A análise inicia-se ao verificar como o veículo jornalístico trata o MPL. No editorial, a primeira menção que reflete esse referencial imagético é a seguinte: "manifestantes que prejudicam seriamente a população". O jornal não faz menção explícita ao MPL, porém mostra visão prévia de como enxerga os integrantes que dele fazem parte. Em seguida, o periódico afirma que o movimento se recusa a acatar uma decisão da justiça que estabelece a necessidade de informar o trajeto da passeata "como tem feito seguidamente, apesar da insistência das autoridades", reafirmando essa visão. Com isso, as primeiras imagens que o jornal repassa são a da irresponsabilidade e a da falta de compromisso do coletivo, pois os manifestantes, segundo o veículo, trazem prejuízo à cidade e não respeitam as regras do jogo democrático.

A desorganização, seja a do movimento, seja a provocada por ele no espaço urbano, serve também de recurso argumentativo para a publicação. Passagens do editorial como "ao contrário do decidido em cima da hora pelo MPL" e o emprego do adjetivo "os desordeiros", no final do texto, apontam para a imagem de desorganização preconcebida do jornal a respeito do Movimento Passe Livre (MPL).

$O$ Estado de S. Paulo traça uma comparação do MPL com as demais manifestações populares, ressaltando ainda mais o caráter "desordeiro" do movimento.

(...) o direito à livre manifestação tem de ser respeitado e não, como vinha acontecendo, utilizado para atropelar outros direitos, como o de ir e vir dos que não participam de protestos ou que, quando se manifestam, o fazem dentro da lei e da ordem. (ORDEM..., 2016, p. A3)

Com essa passagem, o jornal considera legítimo outro movimento, que não causa danos à cidade, sobrepondo-o às manifestações do MPL. Ou seja, ao mesmo tempo em que se coloca a favor dos que "quando se manifestam, o fazem na ordem", põe-se contra os demais.

Outro detalhe importante nessa passagem constitui a referência à frequência das manifestações. A sentença “quando se manifestam” refere-se ao maior espaçamento que os demais movimentos dão entre uma passeata e outra, tática não utilizada pelo Movimento Passe Livre, cuja estratégia consiste em eventos sistemáticos e "com curto intervalo de tempo entre eles, 
de maneira a asfixiar o poder público, fazendo jus ao lema do MPL: 'Se a tarifa não baixar, a cidade vai parar!" (JUDENSNAIDER [et al], 2013, p. 26).

A violência também constitui o valor argumentativo mais utilizado pelo $O$ Estado de S. Paulo para descrever o MPL. Foram selecionadas diversas passagens, nas quais a imagem do movimento é vinculada diretamente a atitudes violentas. Os seguintes trechos "[a polícia] cercou os manifestantes e deteve vários suspeitos com correntes, tesouras, soco inglês e artefatos explosivos, numa clara demonstração de qual era o ânimo de pelo menos boa parte deles. " e "a posição do MPL (...) é preocupante, porque indica que esse grupo está mesmo disposto a afrontar a autoridade" constituem dois exemplos dessa associação do movimento com atos de violência explícita.

Ainda relacionando o movimento à violência, outra tática de argumentação utilizada pelo jornal consiste em associar a imagem do MPL a dos Black Blocs, movimento conhecido pela radicalização e pela depredação das propriedades pública e privada: "não é possivel que os manifestantes e infiltrados queiram livremente bagunçar toda a cidade" e "quem se arrisca a desrespeitá-la [notificação às autoridades sobre trajeto de passeatas na Europa e Estados Unidos] paga o preço da repressão policial e grupos violentos como o Black Bloc têm de acertar contas com a Justiça".

Os manifestantes são colocados no mesmo patamar de delinquentes e de criminosos, com os quais a Justiça deve agir com veemência:

Principalmente se (...) daqui para frente as ações daqueles grupos forem tipificadas em inquéritos policiais como as de membros de organização criminosa. É inaceitável que baderneiros que destroem o patrimônio público e privado sejam detidos, logo liberados e voltem a delinquir. (ORDEM..., 2016, p. A3)

Passando ao segundo momento da análise, tratar-se-á a imagem que o jornal apresenta de si mesmo para legitimar o seu discurso. Logo no primeiro parágrafo, com a expressão "finalmente", o periódico utiliza a autoimagem de fiscalizador do poder público para iniciar seu discurso argumentativo, impondo, assim, sua autoridade como agente social: "finalmente as autoridades encarregadas da segurança pública decidiram (...)". Outro momento em que usa sua imagem para cobrar as autoridades é a passagem na qual menciona o atual prefeito da capital, Fernando Haddad:

Ao contrário do governo do Estado, que tomou o bom caminho, o prefeito Fernando Haddad fica muito mal nessa história, com sua proposta demagógica e de viés eleitoreiro de sugerir ao Ministério Público que tente mediar a relação entre o MPL e a PM (ORDEM..., 2016, p. A3). 
Nos seguintes exemplos destacados do texto, o jornal $O$ Estado de $S$. Paulo utiliza sua posição social para servir de conselheiro às autoridades e à sociedade como um todo: "e preocupante porque indica que esse grupo"; "a regra anunciada (...)é que coloca as coisas em seus devidos lugares"; "se o governo paulista se mantiver firme nessa posição (...). Nesses trechos, torna-se possível perceber o caráter avaliativo do jornal, que faz uma leitura da conjuntura social e se posiciona conforme seus interesses e sua visão editorial. Esse posicionamento de conselheiro advém da função e da imagem que o veículo possui dele mesmo.

Por fim, o jornal vai além de sua posição de fiscalizador. No momento destacado a seguir, passa a ser desafiador do poder público municipal, questionando a competência da prefeitura sobre o assunto da ordem nas manifestações: "aliás, segurança pública é assunto que não diz. respeito ao prefeito".

\section{A VERDADEIRA FACE DO MPL}

O segundo editorial, $A$ Verdadeira Face do MPL (Figura 2), publicado em 17 de janeiro de 2016, na página A3 do jornal, também divide espaço com dois outros editoriais: Manifesto Irrefletido, que questiona a manifestação de um grupo de advogados críticos à operação Lava Jato e O Pior Está Por $V i r$, que trata da alta no desemprego e da falta de perspectivas de melhoras da crise econômica vivida pelo país.

Foram identificados 12 momentos em que o jornal realiza a antecipação das representações do receptor frente ao MPL e oito nos quais o jornal mostra a autoimagem. Torna-se interessante notar que, em dois momentos do discurso, o jornal, ao mesmo tempo em que faz a imagem do outro, projeta a imagem de si a partir da crítica ao movimento.

Nesse editorial, as primeiras duas menções relacionam o MPL a "táticas truculentas" e a "comportamento tortuoso", o que deprecia a imagem do movimento. A primeira novamente expõe o que o jornal considera comportamento violento e, a segunda, destaca o caráter não verdadeiro do discurso empregado pelo grupo. Ratificando essa questão, existe a seguinte citação na sequência do editorial: "desaparece a imagem de bom-mocismo que [o MPL] sempre cultivon e surge a de um grupo aguerrido, frio e calculista (...)".

Outra passagem, em que $O$ Estado de S. Paulo define explicitamente a visão negativa que possui do MPL, aparece com mais intensidade no decorrer do texto. Nele, o jornal considera o movimento como uma "organiz̧ação politizada" que se utiliza de "meios violentos para atingir seus objetivos": 


\section{Figura 2}

\section{A verdadeira face do MPL}

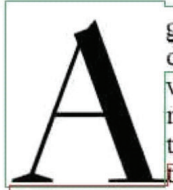

gora não há mais dúvida. Com a divulgação de manual no qual instrui seus militantes e simpatizantes sobre como bloquear vias importantes e empregar outras táticas truculentas para atingir seus objetivos, o Movimento Passe Livre (MPL) confirma as avaliações mais pessimistas sugeridas pelo seu comportamento tortuoso - sobre a sua verdadeira natureza e as suas verdadeiras intenções. Desaparece a imagem de bom-mocismo que sempre cultivou e surge a de um grupo aguerrido, frio e calculista, que não hesita em apelar para o emprego de métodos de ação violentos, que lembram ações precursoras da guerrilha urbana.

"Para aumentar as chances de vitória contra o aumento ( $d a$ tarifa dos transportes coletivos), chegou a hora de começar a travar terminais de ônibus, grandes avenidas e ruas no entorno dos atos para garantir que a cidade pare até que tarifa baixe", diz o manual. Com as minúcias de quem traça um bem pensando plano de batalha, o MPL propõe "sete passos" para parar vastas áreas da cidade e, por esse meio, potencializar os efeitos de suas manifestações, se é que a essa altura tal palavra ain da pode ser empregada para designar suas estripulias.

Primeiro, ensina, é preciso convocar amigos, grupos políticos - e pensar que o MPL se vangloria de ser apartidário -e outras pessoas para participar dos protestos, por meio de mensagens de WhatsApp. Depois, deve-se escolher, em grupo, os locais que serão travados, "durante, depois e em outros dias além do ato". Ou seja, são ações continuadas, que estão a léguas de distância da ideia vendida à população de protestos espontâneos, puros, ditados pela indignação contra a tarifa alta de um serviço ruim, que a seu ver deveria ser gratuito, como se se vivesse num mundo de sonhos onde não é preciso pagar contas.

O manual orienta os grupos embora isso não seja dito, supōe-se que sejam integrados por militantes bem treinados, do contrário não teriam como fazer o que deles se espera - a organizar ações logo pela manhã e dialogar com a população para conseguir sua adesão. "Não podemos fazer essa ação isolada. Temos de convencer os trabalhadores", recomenda.

Outras orientações são fotografar e filmar as ações para divulgá-las e incentivar os participantes das manifestações a repeti-las. Finalmente, propõe-se que se marque uma concentração antes do protesto e que seus participantes sigam "em marcha travando as ruas até o local do grande ato". Isso já aconteceu na manifestação de quinta-feira passada - o ato preliminar foi na Praça da Sé - e o objetivo, mais uma vez, é explorar todas as possibilidades de tumultuar a vida da cidade.

E importante assinalar esses pormenores das instruções do manual porque são eles que dão uma ideia precisa do que é de fato o MPL - uma organização politizada, sim, ao contrário do que ela pretendia ser, e determinada a utilizar meios violentos para atingir seus objetivos. Violência que se revela de várias formas. Uma delas é o bloqueio de vias importantes, com a deliberada intenção de complicar ainda mais o trânsito já difícil e paralisar a cidade, prejudicando a vida de milhões de paulistanos.

Violência não é apenas jogar coquetéis molotov e promover vandalismo. Mas também essa violência explícita, escancarada, faz parte do MPL, embora ele espertamente queira posar de bonzinho. A essa altura, só os ingênuos ainda resistem a admitir que os black blocs são a outra face do MPL. Não se viu até agora por parte desse movimento nenhuma ação concreta para combater a violência dos black blocs, nem mesmo - $\mathrm{O}$ que seria pouco tendo em vista a gravidade do caso - uma palavra de condenação clara do rastro de destruição que eles deixam a cada manifestação.

Essa omissáo so pode ser entendida como cumplicidade. E cumplicidade é crime. Já está mais do que na hora de fazer cair a máscara de movimento pacífico, que o MPL espertamente carrega. A sociedade precisa acordar para essa realidade. Especialmente aquela sua parcela que engrossa as fileiras das manifestações do MPL e, assim, se deixa usar como massa de manobra de inocentes úteis.

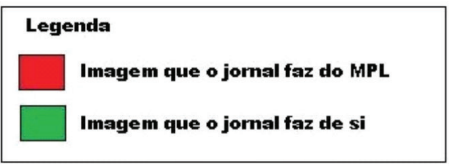


(...) uma organização politizada, sim, ao contrário do que ela pretendia ser, e determinada a utilizar meios violentos para atingir seus objetivos. Violência que se revela de várias formas. Uma delas é o bloqueio de vias importantes, com a deliberada intenção de complicar ainda mais o trânsito já difícil e paralisar a cidade, prejudicando a vida de milhões de paulistanos. (A VERDADEIRA..., 2016, p. A3)

Assim como no editorial Ordem nas Manifestações, o jornal compara o Movimento Passe Livre com os Black Blocs. Desta vez, o veículo os apresenta como uma face da violência explícita do grupo: "(...) mas também essa violência explícita, escancarada, faz parte do MPL(...). A essa altura só os ingênuos ainda resistem a admitir que os black blocs são a outra face do MPL.".

A omissão do movimento frente às atitudes de depredação realizadas pelos Black Blocs torna-se a principal argumentação do jornal nos dois parágrafos seguintes, nos quais mantém as comparações entre os movimentos. Por fim, criminaliza o MPL por sua omissão: "essa omissão só pode ser entendida como cumplicidade. E cumplicidade é crime.".

Além disso, a imagem do Movimento Passe Livre como um grupo incoerente é bastante utilizada durante o editorial por meio de comparações. Nos trechos “(...) são ações continuadas, que estão a léguas de distância da ideia vendida à população (...)" e "(...) supõe-se que sejam integrados por militantes bem treinados (...)", entende-se que o Movimento Passe Livre estaria arquitetando planos para, de modo violento, agir na cidade, contradizendo seu discurso de que é um movimento espontâneo, que se manifesta ocupando as ruas.

Já como autoimagem, o jornal aparece como uma espécie de juiz em alguns trechos, como o em que usa a expressão "agora não há mais dúvida", em referência à "caída de máscaras do MPL”. Esse argumento mostra que o veículo se coloca em um patamar inquestionável frente a seu destinatário, posicionando-se como primeira e última instância julgadora do movimento.

$O$ Estado de S. Paulo também se considera livre para reinterpretar as falas do MPL, utilizando-as como argumento de ataque. Para isso, usa duas expressões "ou seja, são ações continuadas (...)" e "(...) embora isso não seja dito", nas quais dá novo sentido às falas do movimento, na tentativa de desconstruir o discurso utilizado pelo grupo.

Além disso, a publicação chama os leitores para a ação: “já está mais do que na hora de fazer cair a máscara de movimento pacifico, que o MPL espertamente carrega”. Interessante notar que, nessa citação, o discurso do jornal se aproxima do de militância, convocando seus seguidores a agir.

Novamente o jornal utiliza sua posição social para colocar-se no papel de conselheiro, como nos seguintes trechos: "é importante assinalar esses pormenores (...)" e "o que seria pouco tendo em vista a gravidade do caso". 
Em dois momentos, O Estado de S. Paulo coloca, explicitamente, a imagem prévia que tinha do Movimento Passe Livre para construir sua autoimagem. No trecho “(...) e pensar que o MPL se vangloria de ser apartidário”, projeta crítica ao movimento, empregando sua imagem de instituição socialmente estabelecida para validar o discurso. No segundo trecho, o jornal questiona se as ações do Movimento Passe Livre podem realmente ser consideradas manifestações:

“(...) o MPL propõe "sete passos" para parar vastas áreas da cidade e, por esse meio, potencializar os efeitos de suas manifestações, se é que a essa altura tal palavra ainda pode ser empregada para designar suas estripulias (A Verdadeira..., 2016, p. A3, grifo nosso).

Com esse questionamento, ao mesmo tempo em que expõe a imagem que faz do outro, O Estado de S. Paulo aproveita a força de seu discurso e da autoimagem para questionar a legitimidade das manifestações organizadas pelo movimento.

\section{CONCLUS ÃO}

Assim, percebe-se que, nos dois editoriais analisados, o jornal faz antecipação negativa da imagem do Movimento Passe Livre, realizando diversas associações com o objetivo de desconstruir a imagem do MPL como um movimento, além de associá-lo a valores negativos, como a desorganização, o desrespeito ao jogo democrático, a violência, a delinquência e a criminalidade.

Como imagem que faz de si próprio, o jornal ocupa lugares de fiscalizador e de desafiador do poder público, além de se propalar como conselheiro que detém a capacidade de análise fidedigna da realidade como um todo. Por vezes, o veículo posiciona-se como juiz, para, assim, decretar o que deve ser feito ou não com relação às manifestações organizadas pelo MPL e ao próprio movimento. No segundo editorial, torna-se interessante notar a aproximação do veículo com o discurso militante. Ao chamar os leitores para a ação, o jornal acaba por fazer o que mais critica no outro - articular para a ação -, imagem que não projeta a si, mas acaba por reproduzir sem intencionalidade.

Após essa análise, visando a trabalhos futuros, pergunta-se como essa imagem do MPL, construída e divulgada pelo O Estado de S. Paulo, influencia o Movimento Passe Livre e a sociedade de maneira geral, já que a questão da mobilidade urbana tem se tornado cada vez mais essencial para o bom funcionamento das cidades contemporâneas. 


\section{REFERÊENCIAS}

HABERMAS, Jürgen. Mudança estrutural na esfera pública: investigações quanto a uma categoria da sociedade burguesa. 2 ed. Rio de Janeiro: Tempo Brasileiro, 2003.

JUDENSNAIDER, Elena et al. Vinte centavos: a luta contra o aumento. São Paulo: Veneta, 2013.

LIMA. Venício A. de. Mídia, rebeldia urbana e crise de representação. In: MARICATO, Ermínia et al. Cidades rebeldes: Passe Livre e as manifestações que tomaram as ruas do Brasil. São Paulo: Boitempo, 2013. p. 89-94.

O ESTADO DE S. PAULO. A verdadeira face do MPL, 17 jan. 2016. Notas e Informações, p. A3. São Paulo.

O ESTADO DE S. PAULO. Ordem nas manifestações, 14 jan. 2016. Notas e Informações, p. A3. São Paulo.

PÊCHEUX, Michel. Análise automática do discurso. In: GADET, Francoise; HAK, Tony. Por uma análise automática do discurso: uma introdução à obra de Michel Pêcheux. $4^{\mathrm{a}}$ ed. Campinas: Editora da Unicamp, 2010. 